\title{
THE IMPACT OF THE ECONOMIC CRISIS ON MOUNTAIN TOURISM: AN ANALYSIS IN THE CENTRAL PYRENEES REGION IN SPAIN
}

\author{
Victor Orive* \\ Escuela Turismo Universitaria de Zaragoza \\ https://orcid.org/0000-0001-6467-7414 \\ Carmen Elboj** \\ Universidad de Zaragoza \\ http://orcid.org/0000-0003-0937-4861 \\ Diana Valero*** \\ Universidad de Zaragoza/Universidad Nebrija \\ http://orcid.org/0000-0002-3252-076X
}

\begin{abstract}
This article analyses the impact of the 2007 economic crisis on mountain tourism. In order to achieve this objective, we examined more than 300 tourist companies that focus their activity in the Central Pyrenees region in Spain. Through a longitudinal analysis that covers the period from 2006 (the year before the start of the crisis) to 2016 (the date on which the recovery is established), we analysed the evolution of the economic and financial variables. The results of the research indicate that during this period the majority of variables showed losses relative to the values in 2006 .
\end{abstract}

Keywords: company; crisis; mountain tourism; Spain; Pyrenees.

Fecha de recepción; 16 de julio de 2019

Fecha de aceptación: 28 de marzo de 2020

* Escuela Turismo Universitaria de Zaragoza. Plaza Ecce Homo, 3, 50003 ZARAGOZA (España). E-mail: orive@unizar.es

**Universidad de Zaragoza. Calle de Pedro Cerbuna, 12, 50009 ZARAGOZA (España). E-mail: celboj@ unizar.es

*** Universidad de Zaragoza/Universidad Nebrija, Calle de Pedro Cerbuna, 12, 50009 ZARAGOZA (España) / Santa Cruz del Marcenado, 27. 28015 MADRID (España). E-mail: dvalero@nebrija.es 


\section{Impacto económico de la crisis en el turismo de montaña: un análisis para el caso de Los Pirineos}

\section{RESUMEN}

Este artículo analiza el impacto de la crisis de 2007 en el contexto del turismo de montaña. Para alcanzar este objetivo, la investigación analiza más de 300 empresas que desarrollan su actividad en los Pirineos. A través de un análisis longitudinal que incluye el periodo 2006 (fecha previo al inicio de la crisis) y 2016 (momento en el que la recuperación económica ya está asentada) se ha analizado la evolución variables económicas y financieras. Los resultados de la investigación indican que la mayoría de las variables consideradas se han visto reducidas con respecto al año 2006.

Palabras clave: crisis; empresas; España; turismo de montaña; Pirineos.

\section{INTRODUCTION}

During the period 2006-2016 the European economy went through various stages or cycles (Eurostat, 2017). One of the most important cycles, due to its repercussions in both social and economic domains, corresponds to the economic crisis of 2007. This crisis, which came to Europe in 2008, had its origin in the United States and resulted from the sale of subprime mortgages by some financial institutions to insolvent consumers.

The economic crisis has particularly affected countries such as Spain, Italy or Greece, and has materialised in a marked reduction of the gross domestic product (GDP), with notable negative growth rates, increased unemployment, the closing of companies and increases in debt and public deficit. The tourism industry has not been immune to this reality. Especially affected are those countries where tourism represents a large percentage of the GDP. Several studies have investigated the impact of the economic crisis on this particular sector (Angel Menéndez-Plans and Orgaz-Guerrero, 2018; Blázquez-Resino, Amatulli and Pino, 2018; Dogru and Bulut, 2018).

In countries such as Spain, where tourism represents a large percentage of its GDP, it is important to identify and quantify the impact of the economic crisis on the sector, in order to prevent future negative effects. In the coastal areas of Spain, the economic recovery that began between 2010 and 2014 depending the zone, together with the fall in consumer prices, led to the recovery of activity levels seen prior to the crisis (Torres, Ramírez, and Rodríguez, 2014). However, sun and beach tourism, which is predominant in Spain, is not the only tourist model. In this sense, the tourism authorities are betting on new tourist typologies, among which is mountain tourism, that allows diversification of tourist attractions and, with this approach, expands the seasonality that characterises the tourism demand in Spain (Turespaña, 2018).

This article aims to analyse the effects of the economic crisis on Spanish mountain tourism companies. In order to achieve this objective, the research analyses different economic variables (number of employees, operating income, total assets, economic result for the year, 
economic profitability, financial profitability, creation and extinction of tourism companies) for the period between 2006, prior to the crisis, and 2016, the year in which the economic recovery took hold. The tourist companies of the regions of the High Aragon (central Pyrenees) - one of the main areas of mountain tourism of Spain are the study context.

This article is structured as follows. Section 2 reviews the literature on the economic crisis and the tourism sector. In Section 3, a description of nature and mountain tourism is provided. Section 4 describes the analysis variables and the characteristics of the sample. The results of the research are presented in Section 5. Finally, Section 6 contains the conclusions, limitations and proposed future lines of research

\section{ECONOMIC CRISIS AND TOURISM SECTOR}

Tourism is a key economic sector for the Spanish economy. In 2018, last year available, this industry generated $12.3 \%$ of the GDP and employed more than 2.6 million people, a figure that represents almost $12,7 \%$ of the total employment in Spain in the year 2018 (Spanish Statistical Office [INE], 2019). In addition, in that year, more than 83.7 million international tourists, mostly from European Union countries, visited Spain, with Catalonia, the Canary Islands and the Balearic Islands receiving the greatest influx of tourists. Spending by international tourists in Spain exceeded 92,000 million euros that year, representing an increase of 2.8\% over 2018 (Spanish Statistical Office [INE], 2019).

However, the tourism sector of a territory can be affected by three different types of crisis (Nieto et al., 2016). This industry is vulnerable to crises caused by natural disasters (Henderson, 2007; Ritchie, Crotts, Zehrer and Volsky, 2014; Sharpley, 2005), security problems (Araña and León, 2008; Bassil, Saleh and Anwar, 2017; Pizam and Smith, 2000) or economic/financial reasons (Ritchie, Amaya Molinar and Frechtling, 2010;Smeral, 2010; Song and Lin, 2010). Considering this last typology - the object of our investigation - one may observe that the specialised literature in tourism is prolix in the analysis of this phenomenon. Indeed, there are numerous investigations that have addressed and quantified the impact of various economic crises, as have occurred over the last decades in the tourism industry. All this has differentially impacted various contexts and countries.

Thus, one of the first crises analysed was that which took place in the 1970s, stemming from the oil price boom. Solomon and George (1976) investigated the impact of this event on the tourism industry using a sample of tourists from the United States. The results indicated that the crisis affected, in particular, the spending behaviour of these tourists.

The Asian financial crisis of the 1990s has also been analysed by researchers specialising in tourism (Henderson, 1999; Law, 2001; Prideaux, 1999; Prideauxand Witt, 2000). The results of the research highlight the negative impact the crisis have had on tourist demand in Japan, Hong Kong and Australia, and demonstrate the importance of developing public policies to manage economic crises in the tourism industry.

The last global economic crisis originated in the United States in 2007 and resulted from the sale of subprime mortgages by some financial entities to insolvent consumers. This crisis, which reached Europe in 2008, has had important negative consequences on the economies of European countries. In the context of the tourism industry, the literature has analysed the impact of this crisis of in Cyprus (Boukas and Ziakas, 2013), Greece 
(Magoutas, Papadoudis and Sfakianakis, 2018), Italy (Cafiso, Cellini, and Cuccia, 2018) and Spain (García López, Campoy Muñoz, Cardenete Flores and Marchena Gómez, 2018).

The research of Boukas and Ziakas (2013), for example, indicates that the main consequences of the crisis in the Cypriot tourism sector are reflected in fewer international tourist visits, a fall in tourist revenues and a decrease in competitiveness. In addition, it highlights the lack of a comprehensive regulatory plan for tourism planning in Cyprus.

The economic crisis also affected Greece's tourism industry (Papatheodorou and Arvanitis, 2014; Magoutas, Papadoudis and Sfakianakis, 2018). The impact of the crisis has been quantified in terms of hotel tourism consumption. The results of the work indicate that the Greek regions that receive more international tourists have been less affected by the crisis in terms of tourist consumption than those regions whose largest segment of consumers comes from domestic tourism. The authors highlight the importance of internationalising the Greek tourism sector to reduce the effects of the crisis.

Cellini and Cuccia (2014) have investigated how the economic crisis has affected the Italian tourism industry. Their findings highlight that there has been a decrease in hotel revenues and a reduction in the total number of hotel establishments in Italy. Still, the authors emphasise the strength of the Italian tourism sector with respect to other economic sectors. Cafiso, Cellini, and Cuccia (2018) after study the case of Italy (20002012) pointed out how, in times of crisis. Tourists tend to choose closer destinations and thus, Italy received fewer visitors.

In the Spanish context, Torres, Ramírez, and Rodríguez (2014) have analysed the impact of the economic crisis of 2007 on the tourism industry of the Costa del Sol in Andalusia using the number of overnight stays, domestic travellers, international travellers and number of hotels. Their findings highlight that the economic crisis affected the tourism sector to a lesser extent than other sectors of Spain. These authors also found that the economic recovery in the Spanish tourism sector, on the whole, began in the year 2010. This result was later confirmed by the research of Nieto, Román, and Bonillo (2016) and García López, Campoy Muñoz, Cardenete Flores and Marchena Gómez (2018) who point out that the sector's weaknesses are spatial concentration, temporary employment, technological insufficiency and tourist spending far from the intended quality tourism. Other studies focused on how economic crisis affect residents' perceptions of the impacts of tourism, concluding that economic recession causes a significant growth of the residents' support towards tourism, particularly due to a significant decrease in the residents' perception of costs related to such development (Garau-Vadell, Gutierrez-Taño and Diaz-Armas, 2018).

In 2016, last year of our research, 75 million international tourists visited Spain and within this group of tourists, 39.4 million did so with the motivation of looking for sun and beach on the Spanish coasts and islands. In percentage terms, this figure represents $52 \%$ of the total of international tourists. However, the Spanish tourism authorities propose among its objectives in the next years to increase tourism in sectors other than sun and beach tourism. This would include cultural or nature tourism (Turespaña, 2018).

However, it can be seen that the analysis of the impact of the economic crisis on the tourism sector has been dealt with differentially across various historical and territorial contexts, with the sun and beach destinations and the economic crisis of 2007 the most 
analysed contexts. Further, reviewing the relevant literature, one finds a lack of work endeavouring to analyse the impact of the economic crisis in other areas of tourism, such as mountain tourism.

\section{MOUNTAIN TOURISM}

The segment of mountain tourism represents $15 \%$ to $20 \%$ of the total world tourism income according to United Nations data in the framework of the International Year of Mountains (United Nations Environmental Programme [UNEP], 2002) and Price et al. (1997).

This segment of tourism implies a multitude of activities of a very diverse nature. For example, Antar-Ecotono (2004) describes three subgroups within nature tourism that could also be applied to mountain tourism:

(1) Recreational tourism: this includes recreational and recreational activities in nature without degrading it.

(2) Active tourism: sports activities of varying intensity that use natural resources without degrading them.

(3) Ecotourism: the objective is to know and enjoy the natural environment without degrading it, being able to perform physical activities but of low intensity.

This type of tourism has two key factors: on the one hand, the mountain itself (the landscape, its beauty and its quality) and, on the other, the tourism infrastructure. Based on this idea, several studies (Bürki, Elsasser and Abegg, 2003; Gill and Williams, 1994; González, A., Tonazzini, D. and Klarwein, S, 2019; Luthe, Wyss and Schuckert, 2012; Scott, 2006) have focused on how climate change or tourism itself affect the quality of the mountain. However, in this work we do not focus on the first aspect, but rather on the second. The infrastructure and tourism products offered by Spain in mountain tourism are very wide and the activities offered increase year after year. In 2010,Turespaña conducted an analysis of mountain tourism in Spain based on the tourism products of each of the zones and their international potential. The Catalan and Huesca Pyrenees were in the top positions, both in international products and in international tourism (received $27 \%$ and $23.5 \%$, respectively).

At the European level in 2006, Austria, Switzerland, Italy, France and Germany were the most important countries offering mountain tourism (Instituto Nacional de Estadística [Spanish Statistical Office; INE], 2010, p.21). This is wholly justified, given the presence of the Alps in these countries. And in fact, visits to this region represent $40 \%$ of mountain tourism worldwide; further, it was the first mountainous region to develop tourism (Scott, 2006). At the same time, recent research has been focused on this area (Paunović and Jovanović, 2019; Schirpke, Meisch, Marsoner and Tappeiner, 2018; Spandre, François, Verfaillie, Pons, Vernay, Lafaysse, George and Morin, 2019).

However, Spain is growing more and more popular. This is due to the fact that, while mountain tourism was initially very specialised (particularly in its connection with adventure tourism), the destination's offerings have gradually been diversifying and offering more and more activities, such as trail running (Urbaneja, J. S. and Torbidoni, E.I., 2018), wine tourism (Rodríguez, E. B., Luque, D. H., Arnáiz, M. and Gutiérrez, J. I., 2019) or tourism related to sacred mountains (Ceruti, M.C., 2018; Malvárez, M.N. and Oliver, M. 
F., 2019). It currently allows access for all segments of the tourist population, regardless of their physical level or interests. This process has come to be called a democratisation of the mountain (Beedieand Hudson, 2003). Nowadays, in Spain, a cluster analysis performed by Lascu, Manrai, Manrai, and Gan (2018) suggest that natural attractions had the highest importance in the level of tourism, ahead of cultural tourism. Although the most beneficed regions are thus on the coast, in the framework of this research project, Aragon is placed in Cluster 1 (with "High" above average tourist-nights) despite not having coast and being the biggest natural attraction the Pyrenees.

Given that, as noted above, the impact of the economic crisis in the tourism sector has been broad and, further, Spain's objective is to diversify tourism, it is important to know how the economic crisis has affected tourist sectors beyond the sun and beach attractions (Turespaña, 2018). Therefore, considering the country's potential in nature tourism, and specifically mountain tourism, the objective pursued by the research is to analyse and quantify the impact of the economic crisis on mountain tourism in Spain.

\section{METHODOLOGY, SAMPLE CHARACTERISTICS AND ANALYSIS VARIA- BLES}

The methodology used to achieve the objectives of the research is based on the time series approach. Through time series, the evolution of the values of a variable during a given period of time is analysed and compared in a longitudinal fashion. Specifically, the research investigates and graphically represents the evolution of different economicfinancial variables related to business activity and performance. For this, the Microsoft Excel 2007 computer program has been used.

This research considered the Aragonese Pyrenees as the study context. This area is the second most important mountainous region in Spain in terms of the number of international tourist arrivals and the development of tourist infrastructure (ITE, 2010). These figures show a continuous improvement since 2001 according to INE data (2018). Table 1 shows the list of regions of Alto Aragón and the total number of municipalities analysed. As can be seen, the research includes a total of eight counties and 181 municipalities.

Table 1

\section{REGIONS OF ALTO ARAGÓN}

\begin{tabular}{|l|c|}
\hline \multicolumn{1}{|c|}{ Region } & Number of municipalities \\
\hline Alto Gállego & 8 \\
\hline Cinco Villas & 31 \\
\hline Hoya Huesca & 40 \\
\hline Jacetania & 20 \\
\hline Ribagorza & 34 \\
\hline Sobrarbe & 19 \\
\hline Somontano de Barbastro & 29 \\
\hline
\end{tabular}


Research on the economic crisis and the tourism sector has used different variables to analyse this topic. Furthermore, research has been carried out in different countries or in different tourist sectors. For example, in the context of mountain tourism, various authors (Sánchez Pulido, Daries and Cristobal-Fransi, 2016; Moreno-Gené, J., Sánchez-Pulido, L., Cristobal-Fransi, E. and Daries, N. 2018) analyse the profitability and financial situation of alpine ski resorts using the as variables turnovers, economic result for the year, economic profitability or financial profitability.

The economic-financial variables analysed are: the total number of employees (x1), operating income (x2), total assets (x3), economic result for the year (x4), economic profitability (x5) and financial profitability (x6). In addition, the total number of tourist companies created in the regions of Alto Aragón ( $\mathrm{x} 7)$ and the total number of companies that became extinct in that territory (x8) have been included in the analysis.

The longitudinal analysis of the evolution of the variables corresponds to the period between 2006 and 2016. In this manner, the research gathered different moments or cycles of the Spanish economy. Thus, during the years 2006 and 2007, the GDP attained growth rates of over $3 \%$. As of 2008, the Spanish economy began to show lower growth rates, with GDP growth below 1.5\%. During the years between 2009 and 2013, the Spanish economy entered a period of recession, with a very significant decrease in GDP. In 2009, the decrease in growth was 3.5\%. In 2014, the GDP entered a phase of positive growth, reaching an increase of more than $1 \%$. Since 2015, the Spanish economy has attained growth figures of more than 3\%; this rate is continuing at present (Banco de España, 2017).

The analysed data were obtained through the Iberian Balance Sheet Analysis System (SABI). This database collects the annual accounts of the companies that are obliged to report their financial statements. All those companies whose business activities are included in any of the tourism activities, as indicated by the CNAE 2009,were selected for analysis (see Table 2).

Table 2

TOURISM ACTIVITIES 2009

\begin{tabular}{|l|l|}
\hline \multicolumn{2}{|c|}{ Tourism activities CNAE 2009 } \\
\hline $\mathbf{5 5 1 0}$ & Hotels and similar accommodations \\
\hline $\mathbf{5 5 2 0}$ & Tourist accommodations and other short-stay accommodations \\
\hline $\mathbf{5 5 3 0}$ & Campings and parkings for caravan \\
\hline $\mathbf{5 5 9 0}$ & Other accommodations \\
\hline $\mathbf{5 6 1 0}$ & Restaurants and food stalls \\
\hline $\mathbf{7 7 1 1}$ & Car and light motor vehicles rental \\
\hline $\mathbf{7 7 2 1}$ & Rental of leisure and sporting goods \\
\hline $\mathbf{7 9 1 1}$ & Travel agencies activities \\
\hline $\mathbf{7 9 1 2}$ & Tour operator activities \\
\hline $\mathbf{7 9 9 0}$ & Other services for reservations and activities related to them \\
\hline
\end{tabular}




\begin{tabular}{|l|l|}
\hline \multicolumn{2}{|c|}{ Tourism activities CNAE 2009 } \\
\hline $\mathbf{8 5 5 1}$ & Sport and recreational education \\
\hline $\mathbf{9 0 0 1}$ & Scenic arts \\
\hline $\mathbf{9 0 0 2}$ & Auxiliary activities to the scenic arts \\
\hline $\mathbf{9 0 0 3}$ & Artistic and literary creation \\
\hline $\mathbf{9 0 0 4}$ & Showroom managements \\
\hline $\mathbf{9 1 0 2}$ & Museum activities \\
\hline $\mathbf{9 1 0 3}$ & Management of historical places and buildings \\
\hline $\mathbf{9 1 0 4}$ & Activities of botanical gardens, zoos and nature reserves \\
\hline $\mathbf{9 1 0 5}$ & Library Activities \\
\hline $\mathbf{9 1 0 6}$ & File Activities \\
\hline $\mathbf{9 2 0 0}$ & Gambling Activities \\
\hline $\mathbf{9 3 1 1}$ & Sports facilities management \\
\hline $\mathbf{9 3 1 2}$ & Activities of sport clubs \\
\hline $\mathbf{9 3 1 9}$ & Other sport activities \\
\hline $\mathbf{9 3 2 1}$ & Activities of amusement parks and theme parks \\
\hline $\mathbf{9 3 2 9}$ & Other leisure activities \\
\hline
\end{tabular}

\section{RESULTS}

Table 3 shows the evolution of the variables: total number of employees $(\mathrm{x} 1)$, average operating income (x2) and total assets (x3). As can be seen, from 2006 to 2008, the total number of employees hired increased by $14.69 \%$. These hiring figures began to decrease as of 2010, reaching the lowest values of the series in the years 2011, 2012 and 2013, with reductions of 5.99\%, 6.32\% and 7.67\%, respectively. As of 2014, the trend began to reverse; in 2016 the total number of contracted employees was at a level similar to that of 2006.

The evolution of the operating income of all tourism companies shows a decreasing trend during the period between 2007 and 2015. The years in which there was a greater reduction in revenues with respect to the base period are 2012 (decrease of 22.74\%) and 2013 (decrease of 22.16\%). However, in 2016 the operating income of tourism companies obtained values higher than those of the base year and, further, increased by $7.94 \%$ compared to 2006 .

The total active variable presents a different trend from the variables total number of employees and operating income. The total assets of the companies increased with respect to the base period in most years of the series, with the exception of 2011, 2015 and 2016. While the reduction was quite notable in the year 2011, in 2015 and 2016 the decline reached only $0.39 \%$ and $4.26 \%$, respectively. Figure 1 shows the evolution of the variables number of employees, average operating income and total assets of the tourism companies analysed. 
Table 3

EVOLUTION OF THE VARIABLES: TOTAL NUMBER OF EMPLOYEES, AVERAGE OPERATING INCOME AND TOTAL ASSETS (2006=100)

\begin{tabular}{|c|c|c|c|c|c|c|c|}
\hline Año & $\begin{array}{c}\text { Data } \\
\text { Companies } \\
\text { avalaible }\end{array}$ & $\begin{array}{c}\text { Total } \\
\text { number of } \\
\text { employes } \\
\text { (x1) }\end{array}$ & $\begin{array}{c}\text { Total } \\
\text { number of } \\
\text { employees } \\
(\mathbf{2 0 0 6}=100)\end{array}$ & $\begin{array}{c}\text { Average } \\
\text { operating } \\
\text { income } \\
\text { (thousands) } \\
\text { (x2) }\end{array}$ & $\begin{array}{c}\text { Average } \\
\text { operating } \\
\text { income } \\
(\mathbf{2 0 0 6}=\mathbf{1 0 0})\end{array}$ & $\begin{array}{c}\text { Total assets } \\
\text { (thousands) } \\
(\mathbf{x 3 )}\end{array}$ & $\begin{array}{c}\text { Total assets } \\
(\mathbf{2 0 0 6}=100)\end{array}$ \\
\hline $\mathbf{2 0 0 6}$ & 336 & 2.137 & $100,00 \%$ & 207.027 & $100,00 \%$ & 479.326 & $100,00 \%$ \\
\hline $\mathbf{2 0 0 7}$ & 226 & 2.191 & $102,53 \%$ & 154.774 & $74,76 \%$ & 564.262 & $117,72 \%$ \\
\hline $\mathbf{2 0 0 8}$ & 326 & 2.451 & $114,69 \%$ & 170.099 & $82,16 \%$ & 612.777 & $127,84 \%$ \\
\hline $\mathbf{2 0 0 9}$ & 337 & 2.222 & $103,98 \%$ & 156.941 & $75,81 \%$ & 623.091 & $129,99 \%$ \\
\hline $\mathbf{2 0 1 0}$ & 338 & 2.154 & $100,80 \%$ & 176.872 & $85,43 \%$ & 626.461 & $130,70 \%$ \\
\hline $\mathbf{2 0 1 1}$ & 358 & 2.009 & $94,01 \%$ & 174.942 & $84,50 \%$ & 374.711 & $78,17 \%$ \\
\hline $\mathbf{2 0 1 2}$ & 381 & 2.002 & $93,68 \%$ & 159.952 & $77,26 \%$ & 533.191 & $111,24 \%$ \\
\hline $\mathbf{2 0 1 3}$ & 407 & 1.973 & $92,33 \%$ & 161.157 & $77,84 \%$ & 505.496 & $105,46 \%$ \\
\hline $\mathbf{2 0 1 4}$ & 399 & 2.042 & $95,55 \%$ & 176.185 & $85,10 \%$ & 482.813 & $100,73 \%$ \\
\hline $\mathbf{2 0 1 5}$ & 399 & 2.122 & $99,30 \%$ & 191.571 & $92,53 \%$ & 477.934 & $99,71 \%$ \\
\hline $\mathbf{2 0 1 6}$ & 389 & 2.144 & $100,33 \%$ & 223.463 & $107,94 \%$ & 458.887 & $95,74 \%$ \\
\hline
\end{tabular}

Figure 1

EVOLUTION OF THE VARIABLES: TOTAL NUMBER OF EMPLOYEES, AVERAGE OPERATING INCOME AND TOTAL ASSETS (2006=100)

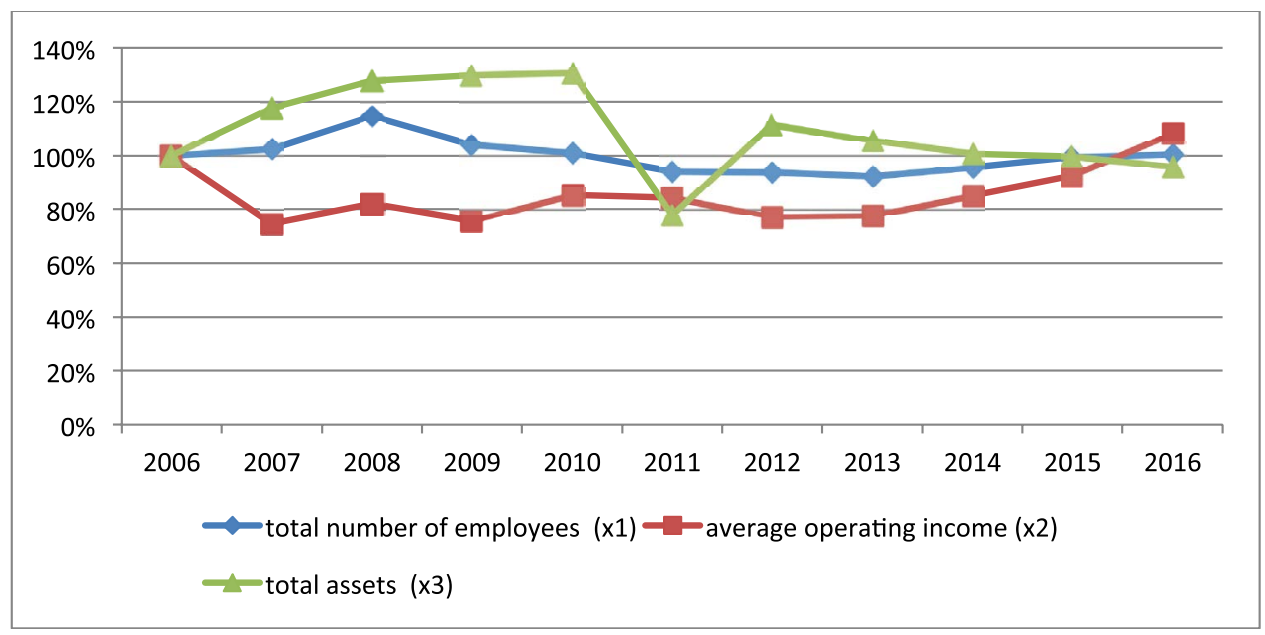


Figure 2 shows the evolution of the economic result of the year (x4) for the set of tourism companies analysed. As can be seen, in $200644.04 \%$ of all companies had a negative economic result. During the period between 2009 and 2014, more than half the companies obtained a negative economic result, with 2011, 2012 and 2013 yielding the highest percentages. Thus, for these 3 years the percentages are greater than $60 \%$. As of 2015 , the percentage of companies with a negative economic result has been decreasing, reaching $39.46 \%$ in 2016 . In addition, the percentage of companies with a profit of more than 10,000 euros increased significantly in 2016, compared to other years of the data series (reaching 32.02\%).

Figure 2

EVOLUTION OF THE ECONOMIC RESULT OF THE YEAR

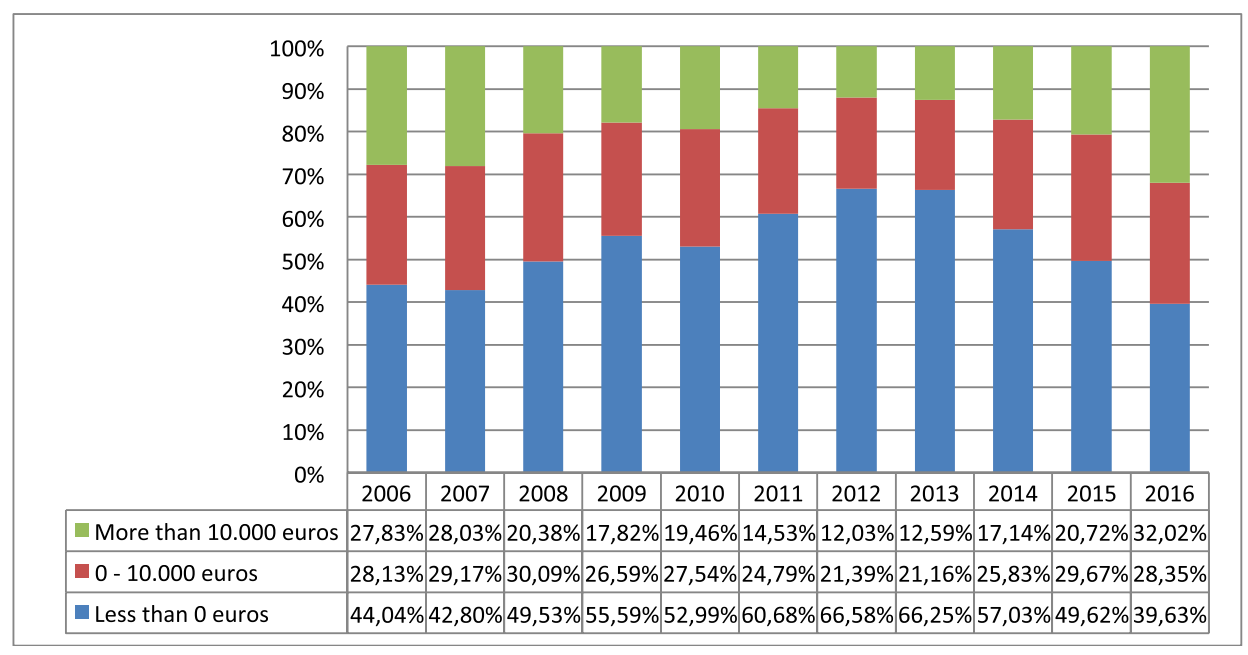

The evolution of the economic profitability of companies (x5), that is, the relationship between the benefits before the payment of interest and taxes (BAII) obtained and the assets used, is shown in Figure 3. The results show a negative economic return of $44.64 \%$ of the companies in the year 2006, while only $11.61 \%$ realised economic profitability of more than $15 \%$ (i.e. for every 100 euros companies invested in assets, the BAII obtained was 15 or more euros). Economic profitability was negative for more than half the companies analysed during the years 2009 to 2014. The years 2011, 2012 and 2013 stand out, with figures of negative economic profitability for more than $58 \%$ of the companies. This trend began to decrease in 2015 and, in 2016 the situation reversed, with a greater percentage of companies with a positive economic return than a negative return. In addition, the percentage of companies with an economic return of more than $15 \%$ reached $14.40 \%$ in 2016.

Figure 4 shows the evolution of financial profitability (x6). This variable reflects the relationship between the net benefits obtained by the company and their own resources 
used for it, that is, whether the activity performed generated profitability for the shareholders and/or company owners. As can be observed, $32.74 \%$ of the companies obtained a negative financial return in 2006, while $42.86 \%$ obtained a financial return of greater than $15 \%$ (or 15 euros net profit for every 100 euros of shareholder investment, after subtracting interest on financing and taxes). During the period between 2010 and 2014, more than $40 \%$ of the companies obtained a negative financial return. This result was very extensive for the years 2011, 2012 and 2013. However, this situation changed after 2015 . In 2016 , only $29.56 \%$ of the tourism companies had a negative profitability. On the other hand, the percentage of companies with a financial return of more than $15 \%$ was relatively low for the period between 2009 and 2014. This situation also changed in 2016 .

In another regard, the total number of tourist companies created in the regions of Alto Aragón (x7) during the period 2006-2016 was 229. These companies fell into various subsectors of activity: restaurants and food stalls (34.93\%), hotels and similar accommodations (15.28\%) and short-stay tourist accommodations (7.86\%; see Figure 5). Finally, the total number of companies that became extinct $(\mathrm{x} 8)$ throughout the analysis period was 52. If we analyse this result according to the activity subsector, it can be seen that the highest percentages of extinguished companies correspond to hotels and accommodations (23.08\%), followed by restaurants and food stalls (19.23\%) and sports activities $(17.31 \%)$. These results are shown in Figure 6.

Figure 3

\section{ECONOMIC PROFITABILITY OF COMPANIES}

\begin{tabular}{|c|c|c|c|c|c|c|c|c|c|c|c|}
\hline \multicolumn{12}{|l|}{$100 \%$} \\
\hline $90 \%$ & & & & & & & & & & & \\
\hline $80 \%$ & & & & & & & & & & & \\
\hline $70 \%$ & & & & & & & & & & & \\
\hline $60 \%$ & & & & & & & & & & & \\
\hline $50 \%$ & & & & & & & & & & & \\
\hline $40 \%$ & & & & & & & & & & & \\
\hline $30 \%$ & & & & & & & & & & & \\
\hline $20 \%$ & & & & & & & & & & & \\
\hline \multirow{2}{*}{$\begin{array}{r}10 \% \\
0 \%\end{array}$} & & & & & & & & & & & \\
\hline & 2006 & 2007 & 2008 & 2009 & 2010 & 2011 & 2012 & 2013 & 2014 & 2015 & 2016 \\
\hline More than $15 \%$ & $11,61 \%$ & $11,65 \%$ & $6,75 \%$ & $5,05 \%$ & $8,28 \%$ & $5,87 \%$ & $6,05 \%$ & $5,40 \%$ & $7,52 \%$ & 9,29\% & $14,40 \%$ \\
\hline - (10\% - 15\%] & $5,06 \%$ & $6,39 \%$ & $3,68 \%$ & $2,37 \%$ & $2,66 \%$ & $3,08 \%$ & $1,84 \%$ & $2,46 \%$ & $4,26 \%$ & $5,76 \%$ & $5,60 \%$ \\
\hline (7\% - 10\%] & $4,76 \%$ & $2,26 \%$ & $3,68 \%$ & $3,26 \%$ & $2,66 \%$ & $3,07 \%$ & $3,15 \%$ & $1,47 \%$ & $3,26 \%$ & $5,01 \%$ & $7,20 \%$ \\
\hline ( $5 \%$-7\%] & $3,87 \%$ & $5,64 \%$ & $6,13 \%$ & $3,86 \%$ & $4,14 \%$ & $3,35 \%$ & $2,10 \%$ & $2,46 \%$ & $4,51 \%$ & $4,26 \%$ & $6,43 \%$ \\
\hline (2\% - 5\%] & $10,42 \%$ & $10,90 \%$ & $13,80 \%$ & $12,76 \%$ & $8,88 \%$ & $7,54 \%$ & $7,09 \%$ & $8,60 \%$ & $10,53 \%$ & $12,78 \%$ & $11,35 \%$ \\
\hline (0\% - 1\%] & $10,71 \%$ & $10,90 \%$ & $9,82 \%$ & $12,46 \%$ & $15,09 \%$ & $10,61 \%$ & $11,29 \%$ & $11,06 \%$ & $8,77 \%$ & $9,02 \%$ & $9,77 \%$ \\
\hline Less than $0 \%$ & $44,64 \%$ & $47,37 \%$ & $47,55 \%$ & $54,01 \%$ & $52,37 \%$ & $58,94 \%$ & $64,30 \%$ & $64,13 \%$ & $55,89 \%$ & $48,37 \%$ & $38,82 \%$ \\
\hline
\end{tabular}


Figure 4

EVOLUTION OF FINANCIAL PROFITABILITY

\begin{tabular}{|c|c|c|c|c|c|c|c|c|c|c|c|}
\hline \multicolumn{12}{|l|}{$\begin{array}{r}100 \% \\
90 \%\end{array}$} \\
\hline $80 \%$ & & & & & & & & & & & \\
\hline $70 \%$ & & & & & & & & & & & \\
\hline $60 \%$ & & & & & & & & & & & \\
\hline $50 \%$ & & & & & & & & & & & \\
\hline $40 \%$ & & & & & & & & & & & \\
\hline $30 \%$ & & & & & & & & & & & \\
\hline $20 \%$ & & & & & & & & & & & \\
\hline \multirow{2}{*}{$\begin{array}{r}10 \% \\
0 \%\end{array}$} & & & & & & & & & & & \\
\hline & 2006 & 2007 & 2008 & 2009 & 2010 & 2011 & 2012 & 2013 & 2014 & 2015 & 2016 \\
\hline Más de 15\% & $42,86 \%$ & $45,49 \%$ & $31,60 \%$ & $30,27 \%$ & $28,11 \%$ & $26,54 \%$ & $25,98 \%$ & $27,52 \%$ & $29,32 \%$ & $35,09 \%$ & $40,87 \%$ \\
\hline De $10 \%$ a $15 \%$ & $4,17 \%$ & $4,51 \%$ & $5,83 \%$ & $4,45 \%$ & $4,73 \%$ & $5,59 \%$ & $3,15 \%$ & $6,46 \%$ & $6,27 \%$ & $4,76 \%$ & $4,88 \%$ \\
\hline De $7 \%$ a $10 \%$ & $2,98 \%$ & $2,26 \%$ & $6,13 \%$ & $4,15 \%$ & $3,25 \%$ & $2,51 \%$ & $1,84 \%$ & $63,19 \%$ & $2,76 \%$ & $4,51 \%$ & $5,66 \%$ \\
\hline De $5 \%$ a $7 \%$ & $2,98 \%$ & $3,38 \%$ & $3,37 \%$ & $4,45 \%$ & $2,96 \%$ & $2,51 \%$ & $2,10 \%$ & $6 \quad 1,72 \%$ & $3,51 \%$ & $4,26 \%$ & $4,11 \%$ \\
\hline De $2 \%$ a $5 \%$ & $6,25 \%$ & $5,64 \%$ & $5,21 \%$ & $6,23 \%$ & $9,17 \%$ & $7,82 \%$ & $6,30 \%$ & $6,3,37 \%$ & $7,77 \%$ & $6,27 \%$ & $6,68 \%$ \\
\hline De $1 \%$ a $2 \%$ & $2,38 \%$ & $2,63 \%$ & $2,45 \%$ & $5,34 \%$ & $1,78 \%$ & $1,68 \%$ & $3,41 \%$ & $6 \quad 1,47 \%$ & $2,26 \%$ & $2,01 \%$ & $2,83 \%$ \\
\hline Menos del 0\% & $32,74 \%$ & $32,71 \%$ & $38,65 \%$ & $39,17 \%$ & $43,20 \%$ & $46,09 \%$ & $52,23 \%$ & $50,12 \%$ & $42,61 \%$ & $37,09 \%$ & $29,56 \%$ \\
\hline
\end{tabular}

Figure 5

TOTAL NUMBER OF TOURIST COMPANIES CREATED IN THE REGIONS OF ALTO ARAGÓN

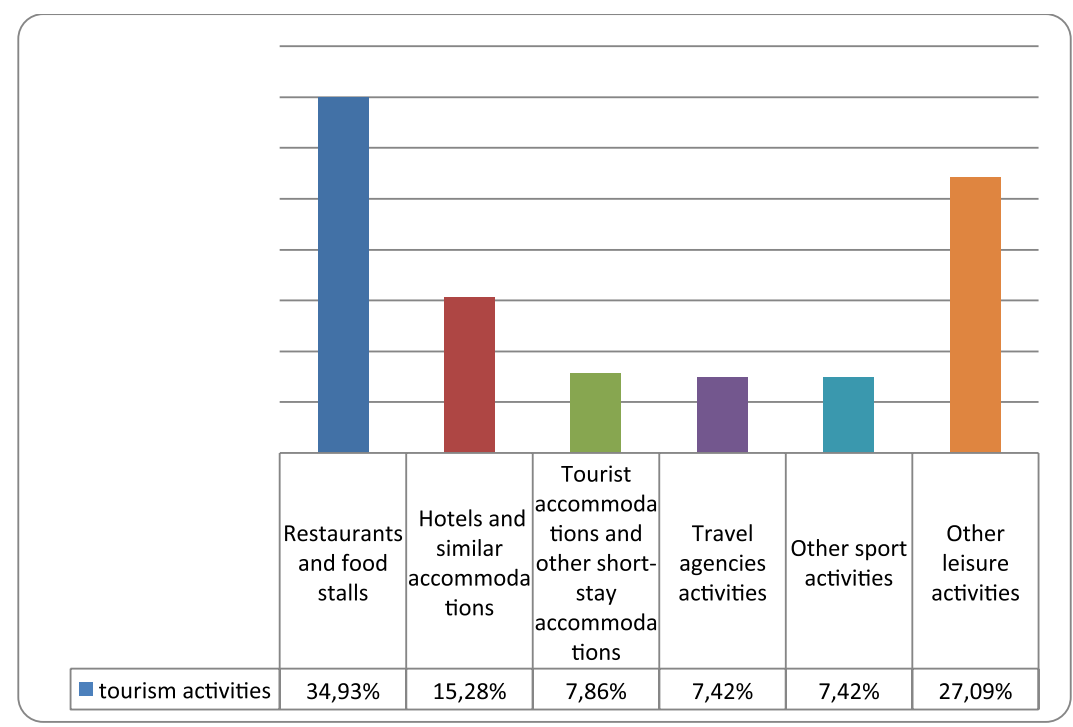

Cuadernos de Turismo, 47, (2021), 85-102 


\section{Figure 6 \\ TOTAL NUMBER OF COMPANIES THAT BECAME EXTINCT (2006-2016)}

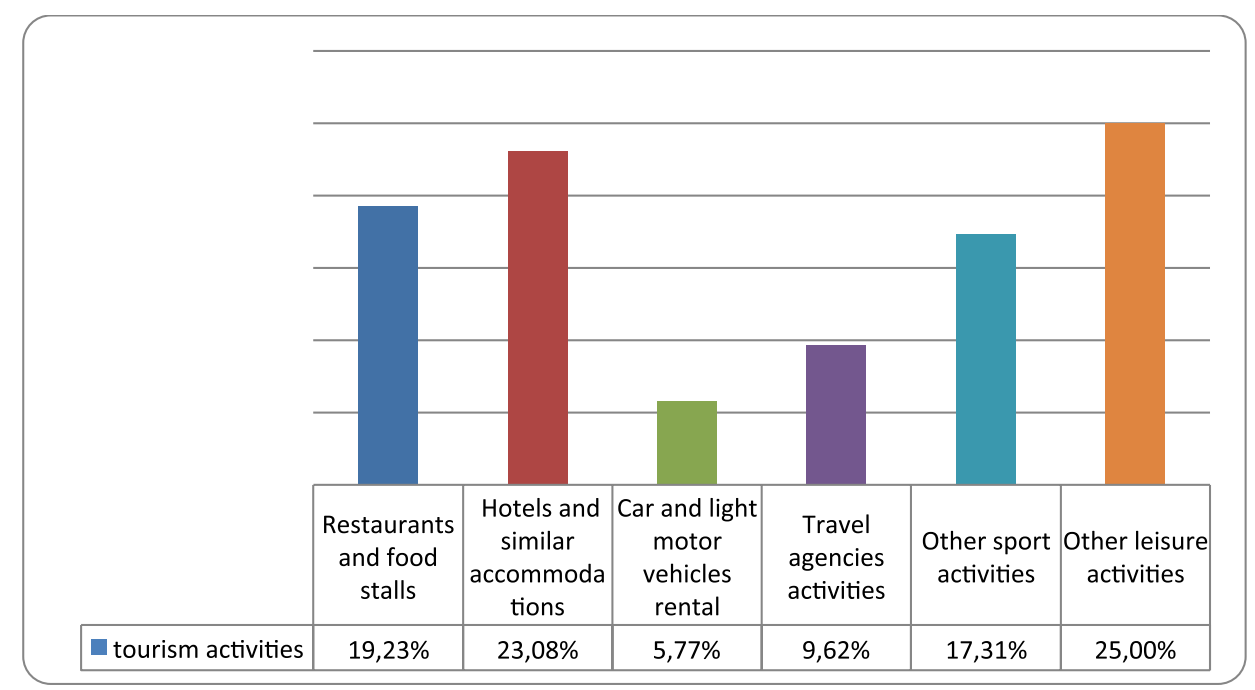

\section{CONCLUSIONS}

During the last decades, the tourism sector has made a notable contribution to the Spanish economy in terms of employment, collection of public income and contribution to GDP. However, the last economic crisis, which arose in the United States in 2007, has significantly affected various economic industries, including the tourist industry. This paper analyses the impact of the economic crisis of 2007 on the Spanish tourism sector. In particular, the research deals with mountain tourism, a sector with a high growth potential but with little development in terms of scientific research.

To carry out our analysis, we used a longitudinal approach was used, focusing on the period between 2006, the date prior to the start of the crisis, and 2016, by which some recovery has been seen. A range of economic and financial variables, including the total number of employees hired, operating income, total assets, the economic result for the year, economic profitability, financial profitability, companies created, and companies extinguished, were used. All these factors were considered for a total of more than 300 tourist companies operating in the central Pyrenees and that appear in the database of the System of Analysis of Iberian Balances (SABI).

The results of the analysis indicate that most of the variables decreased, in comparison to the values seen in 2006. This reduction is very notable for the years 2011, 2012 and 2013. In this sense, losses for these years are reflected in employment (in figures close to $7 \%$ ), reduction in operating income (by 23\%) and annual negative economic result (in more than $60 \%$ of the tourism businesses examined). The economic and financial profitability for these years was $0 \%$ in more than half the companies. During the analysis period, 229 new 
tourism companies were created, but already 52 have ceased their activity. The findings show that, until 2016, tourist companies in this region did not obtain values equal or superior to those of the year 2006 in the set of variables considered. Further, it would appear that the 2007 economic crisis differentially affected various segments of the Spanish tourism industry: the sun and beach sector began to recover prior to the second crisis in 2010 .

The economic and financial results obtained by the group of companies are not optimal. For this reason, the administration must propose actions that manage to encourage companies to achieve higher economic income and / or a decrease in costs. Thus, it is possible that the economic profitability of the sector will vary and reach higher figures. In addition, companies must collaborate and research cooperation agreements. These actions are necessary because mountain tourism can promote the diversification and sustainability of the tourism industry in the long term and address the seasonality that attends the tourist demand in Spain. At the same time, mountain tourism is a source of income for regions that are currently losing population in Spain and, therefore, government support for initiatives to improve this sector implies a much-needed population consolidation

It is important to points out the limitations of this research, first its exploratory nature and the geographical limitation of the study. At the same time, as we have not limited our research to a specific area of mountain tourism, the analyses carried out have been based on ratios, a division by subsectors would allow for deeper econometric analyses. Finally, it is important to underscore that the research carried out focused on a single context of study: the Central Pyrenees.

Future research should therefore be directed at other national and international territories where mountain tourism is practised. As well, it did not include organisations that are not obliged to present their annual accounts (for example, foundations); further, investigations could examine their own course of economic recovery. One of the main future work lines should be analyse each tourism subsector individually and perform a statistical analysis based on regressions for each tourism subsector. Besides, we could include variables not considered in this study (gross margin, EBIT, etc.) and use qualitative techniques that help to know the opinions of the managers of the companies with respect to the object of study of the investigation. Finally, it may be of interest to compare the results obtained with the impact of the crisis on tourist companies operating in sun and beach destinations.

\section{REFERENCES}

ANGEL, K., MENÉNDEZ-PLANS, C. and ORGAZ-GUERRERO, N. (2018). "Risk management: comparative analysis of systematic risk and effect of the financial crisis on us tourism industry”, International Journal of Contemporary Hospitality Management, $\mathrm{n}^{\circ} 7$, pp. 36-38.

ANTAR-ECOTONO, U.T.E. (2004): El turismo de naturaleza en España y su plan de impulso. Madrid, Ministerio de Industria, Turismo y Comercio.

ARAÑA, J.E. and LEÓN, C.J. (2008): "The impact of terrorism on tourism demand", Annals of Tourism Research, vol. 35, pp. 299-315. 
BASSIL, C., SALEH, A.S. and ANWAR, S. (2017): "Terrorism and tourism demand: A case Santa Cruz del Marcenado, 27BASSSILstudy of Lebanon, Turkey and Israel”, Current Issues in Tourism, vol. 22, pp. 1-21.

BEEDIE, P. and HUDSON, S. (2003): "Emergence of mountain-based adventure tourism", Annals of Tourism Research, vol. 30, pp. 625-643.

BLÁZQUEZ-RESINO, J. J., AMATULLI, C. and PINO, G. (2018): "Private label in the tourism industry: the effects of economic crises". In Digital marketing and consumer engagement: concepts, methodologies, tools, and applications, pp. 1683-1708.

BOUKAS, N. and ZIAKAS, V. (2013): "Impacts of the global economic crisis on Cyprus tourism and policy responses", International Journal of Tourism Research, vol. 15, pp. 329-345.

BÜRKI, R., ELSASSER, H. and ABEGG, B. (2003, April): “Climate change-impacts on the tourism industry in mountain areas". In Proceedings of the First International Conference on Climate Change and Tourism, pp. 9-11.

CAFISO, G., CELLINI, R. and CUCCIA, T. (2018). "Do economic crises lead tourists to closer destinations? Italy at the time of the great recession", Papers in Regional Science, vol. 97 (2), pp. 369-386.

CELLINI, R. and CUCCIA, T. (2014): The tourism industry in Italy during the Great Recession (2008-12): What data show and suggest. MPRA Paper $\mathrm{n}^{\circ}$. 62473, pp. 1-27.

CERUTI, M.C. (2018): "De la colina de Wawel a los Altos Tatras: patrimonio, turismo y dimensión sagrada de la montaña en Malopolska (Polonia) ", Cuadernos Universitarios, $\mathrm{n}^{\circ} 11$, pp. 95-114.

DOGRU, T. and BULUT, U. (2018): "Is tourism an engine for economic recovery? Theory and empirical evidence", Tourism Management, vol. 67, pp. 425-434.

EGATUR (2016): Encuesta de gasto turístico. Retrieved from: http://www.ine.es/daco/ daco42/egatur/egatur1216.pdf

EUROSTAT (2017): National Accounts. Retrieved from: http://ec.europa.eu/eurostat

GARAU-VADELL, J.B., GUTIERREZ-TAÑO, D. and DIAZ-ARMAS, R. (2018): "Economic crisis and residents' perception of the impacts of tourism in mass tourism destinations", Journal of Destination Marketing and Management, vol. 7, pp. 68-75.

GARCÍA LÓPEZ, A.M., CAMPOY MUÑOZ, M.D.P., CARDENETE FLORES, M.A. and MARCHENA GÓMEZ, M.J. (2018): "El sector turístico andaluz durante la crisis económica y su impacto en el desarrollo regional”, Revista de Estudios Andaluces, $\mathrm{n}^{\circ}$ 36, pp. 71-97.

GILL, A. and WILLIAMS, P. (1994): "Managing growth in mountain tourism communities", Tourism Management, vol. 15, pp. 212-220.

GONZÁLEZ, A., TONAZZINI, D. and KLARWEIN, S. (2019): Coherencia política del turismo de montaña y el cambio climático: comarca de la Jacetania (Pirineo Aragonés). Retrieved from: http://www.ecounion.eu/wp-content/uploads/2019/08/Informe_ JacetaniaPirineoAragon\%C3\%A9s_5junio2019-1.pdf

HENDERSON, J.C. (1999): "Managing the Asian financial crisis: Tourist attractions in Singapore", Journal of Travel Research, vol. 38, pp. 177-181. 
HENDERSON, J.C. (2007): "Corporate social responsibility and tourism: Hotel companies in Phuket, Thailand, after the Indian Ocean tsunami”, International Journal of Hospitality Management, vol. 26 (1), pp. 228-239.

INSTITUTO NACIONAL DE ESTADISTICA [Spanish Statistical Office; INE]. (2017): Cuenta satélite del turismo en España. Retrieved from: http://www.ine.es/prensa/ cst_2016.pdf

INSTITUTO NACIONAL DE ESTADISTICA [Spanish Statistical Office; INE]. (2019): International tourist expenditure by main reason for the trip. Retrieved from: https:// www.ine.es/jaxiT3/Tabla.htm?t=23995

INSTITUTO DE TURISMO DE ESPAÑA (ITE) (2010): Estudios de productos turísticos: Turismo de Montaña. Retrieved from: https://static.hosteltur.com/web/uploads/2009/04/ ffc71ec51176f15c.pdf

LASCU, D., MANRAI, L., MANRAI, A. and GAN, A. (2018): “A cluster analysis of tourist attractions in Spain: natural and cultural traits and implications for global tourism", European Journal of Management and Business Economics, vol. 27 (3), pp. 218-230.

LAW, R. (2001): "The impact of the Asian financial crisis on Japanese demand for travel to Hong Kong: A study of various forecasting techniques", Journal of Travel and Tourism Marketing, vol. 10 (2-3), pp. 47-65.

LUTHE, T., WYSS, R. and SCHUCKERT, M. (2012): "Network governance and regional resilience to climate change: Empirical evidence from mountain tourism communities in the Swiss Gotthard region", Regional Environmental Change, vol. 12, pp. 839-854.

MAGOUTAS, A., PAPADOUDIS, G. and SFAKIANAKIS, G. (2018): "Determinants of profitability in the greek tourism sector-assessing the effect of the crisis", International Journal of Tourism Policy, VOL.8 (1), pp. 65-72.

MALVÁREZ, M.N. and OLIVER, M.F. (2019): “Tres santuarios y tres modelos de gestión turística en la Montaña Sagrada de Randa (Mallorca) ", Cuadernos de Turismo, $\mathrm{n}^{\mathrm{o}} 43$, pp. 381-406.

MORENO-GENÉ, J., SÁNCHEZ-PULIDO, L., CRISTOBAL-FRANSI, E. and DARIES, N. (2018): "The economic sustainability of snow tourism: the case of ski resorts in Austria, France, and Italy”, Sustainability, vol. ${ }^{\circ} 10$ (9), pp. 3012.

NEPAL, S.K. (2002): "Mountain ecotourism”, Mountain Research and Development, vol. 22 (2), pp. 104-109.

NEPAL, S.K. (2004): Sustaining mountain communities: Residents' responses to tourism development in Valemount, British Columbia. Report submitted to the Northern Land Use Institute, University of Northern British Columbia, Canada.

NIETO, J.L., ROMÁN, I. and BONILLO, D. (2016): "La crisis económica y el turismo internacional en España”, International Journal of Scientific Management Tourism, vol. 2, pp. 271-283.

PAPATHEODOROU, A. and ARVANITIS, P. (2014): "Tourism and the economic crisis in Greece: Regional perspectives", Région et Développement, vol. 39, pp. 183-203.

PAUNOVIĆ, I. and JOVANOVIĆ, V. (2019): "Sustainable mountain tourism in word and deed: a comparative analysis in the macro regions of the alps and the dinarides". Acta Geographica Slovenica, vol. 59 (2), pp. 59-71. 
PIZAM, A. and SMITH, G. (2000): "Tourism and terrorism: A quantitative analysis of major terrorist acts and their impact on tourism destinations", Tourism Economics, vol. 6 (2), pp. 123-138.

PRICE, M.F., MOSS, L.A.G. and WILLIAMS, P.W. (1997): "Tourism and amenity migration”. In B. Messerlu and J.D. Ives (Eds.) Mountains of the world: A global priority (pp. 249-280). Carnforth, UK, Parthenon.

PRIDEAUX, B. (1999): "Tourism perspectives of the Asian financial crisis: Lessons for the future", Current Issues in Tourism, vol. 2, pp. 279-293.

PRIDEAUX, B. and WITT, S.F. (2000): "The impact of the Asian financial crisis on Australian tourism", Asia Pacific Journal of Tourism Research, vol. 5 (1), pp. 1-7.

RITCHIE, B.W., CROTTS, J.C., ZEHRER, A. and VOLSKY, G.T. (2014): “Understanding the effects of a tourism crisis: The impact of the BP oil spill on regional lodging demand", Journal of Travel Research, vol. 53 (1), pp. 12-25.

RITCHIE, J.R.B., AMAYA MOLINAR, C.M. and FRECHTLING, D.C. (2010): "Impacts of the world recession and economic crisis on tourism: North America", Journal of Travel Research, vol. 49 (1), pp. 5-15.

RICHINS, H., and HULL, J. (Eds.). (2016): Mountain tourism: Experiences, communities, environments and sustainable futures. Wallingford, UK: CABI.

RODRÍGUEZ, E.B., LUQUE, D.H., ARNÁIZ, M.M. and GUTIÉRREZ, J.I.P. (2019): “Turismo y desarrollo vitivinícola en espacios de montaña con "alta densidad patrimonial", Cuadernos de Turismo, $\mathrm{n}^{\circ}$ 43, pp. 97-122.

SÁNCHEZ PULIDO, L.; DARIES, N. and CRISTOBAL-FRANSI, E. (2016): "Economic sustainability and financial situation of the alpine ski resorts on the Catalan Pyrenees", Intangible Capital, vol. 12, pp. 1.451-1.483.

SCHIRPKE, U., MEISCH, C., MARSONER, T. and TAPPEINER, U. (2018): "Revealing spatial and temporal patterns of outdoor recreation in the European Alps and their surroundings". Ecosystem Services, vol. 31, pp. 336-350.

SCOTT, D. (2006): "Global environmental change and mountain tourism", en Tourism and Global Environmental Change, pp. 54-75.

SHARPLEY, R. (2005): "The tsunami and tourism: A comment", Current Issues in Tourism, vol. 8, pp. 344-349.

SMERAL, E. (2010): "Impacts of the world recession and economic crisis on tourism: Forecasts and potential risks", Journal of Travel Research, vol. 49 (1), pp. 31-38.

SPANDRE, P., FRANÇOIS, H., VERFAILLIE, D., PONS, M., VERNAY, M., LAFAYSSE, M., GEORGE, E. and MORIN, S. (2019): "Winter tourism under climate change in the pyrenees and the french alps: relevance of snowmaking as a technical adaptation", Cryosphere, vol. 13, pp. 1.325-1.347.

SOLOMON, P.J. and GEORGE, W.R. (1976):“An empirical investigation of the effect of the energy crisis on tourism", Journal of Travel Research, vol. 14 (3), pp. 9-13.

SONG, H., ANDLIN, S. (2010): "Impacts of the financial and economic crisis on tourism in Asia", Journal of Travel Research, vol. 49 (1), pp. 16-30.

TORRES, E., RAMÍREZ, R. and RODRÍGUEZ, B. (2014): “La crisis económica en el sector turístico. Un análisis de sus efectos en la costa del sol", Revista de Análisis Turístico, $\mathrm{n}^{\circ}$ 12, pp. 11-18. 
TURESPAÑA (2018): Plan Estratégico de Marketing 2018-2020. Extraído de: http:// www.tourspain.es/es-es/VDE/Documentos\%20Plan\%20Estratgico\%20de\%20Marketing/PEM\%2018-20.pdf

UNITED NATIONS ENVIRONMENTAL PROGRAMME, UNEP (2002): Mountains. United Nations Environmental Programme. Retrieved from: https://www.ourplanet. $\mathrm{com} / \mathrm{wcmc} / \mathrm{pdfs} / \mathrm{mountains.pdf}$

URBANEJA, J.S. and TORBIDONI, E.I.F. (2018): "El trail running (carreras de o por montaña) en España. Inicios, evolución y (actual) estado de la situación", Retos: Nuevas Tendencias en Educación Física, Deporte y Recreación, n 33, pp. 123-128. 